\title{
Investigation of Leisure Strategies of Sports Educated Students
}

\section{Huseyin Aslan ${ }^{1}$ Osman Imamoglu ${ }^{2}$}

${ }^{i}$ Selcuk University, Faculty of Sciences, Konya, Turkey.

Email:huseyinaslann6@gmail.com

'Tasar Dogu Faculty of Sports Sciences, Ondokuz Mayis University, Samsun, Turkey.

Email:osmani55@hotmail.com

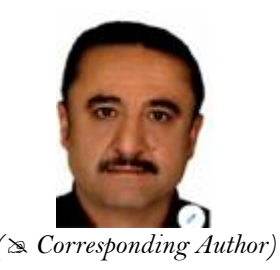

( Corresponding Author)

\begin{abstract}
In this study, it was aimed to investigate Leisure time strategies of sports educated students, who going to Fitness Centers. In addition to sports training, the effect of whether or not to compete as a contestant was also examined for Leisure Strategies. A total of 543 men on fitness centers filled up the Scala "Leisure Strategy Scale" before training. Independent t-test in paired comparisons and one-way analysis of variance (ANOVA) in multiple comparisons and LSD tests were used to determine the difference. A statistically significant difference was found in the leisure strategy subscales and total score according to the age category of University of students $(p<0.05)$. In leisure friendship, the scores of 20 years and under and 21-23 age groups are higher than in the 24 years old and above age group in case of temporary coping and mood improvement. A significant difference was found in all subscales and total scale scores in comparison of leisure strategy subscale and total scores according to income $(p<0.05)$.Conclusion: In addition to sports education, leisure strategies of university students doing sports in Fitness centers differ according to age category and income status. It has that whether or not participating in competitions in sports training students, who going fitness Center does not have a different effect in terms of leisure strategies. In terms of leisure strategies, this study is recommended to be done according to the status of being an amateur and professional athlete in sports-inclined students.
\end{abstract}

Keywords: Student, Leisure, Mood, Friendship.

Citation | Huseyin Aslan; Osman Imamoglu (2020). Investigation of Leisure Strategies of Sports Educated Students. Asian Journal of Education and Training, 6(3): 468-473

History:

Received: 24 April 2020

Revised: 3 June 2020

Accepted: 1 July 2020

Published: 13 July 2020

Licensed: This work is licensed under a Creative Commons Attribution 3.0 License $(\mathrm{cc}) \mathbf{E r}$

Publisher: Asian Online Journal Publishing Group
Acknowledgement: Both authors contributed to the conception and design of the study.

Funding: This study received no specific financial support.

Competing Interests: The authors declare that they have no conflict of interests.

Transparency: The authors confirm that the manuscript is an honest, accurate, and transparent account of the study was reported; that no vital features of the study have been omitted; and that any discrepancies from the features of the study have been omitted
study as planned have been explained.

study as planned have been explained.
Ethical: This study follows all ethical practices during writing.

\section{Contents}

1. Introduction

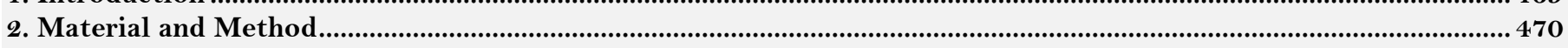

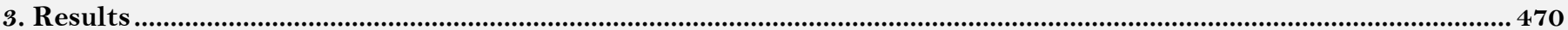

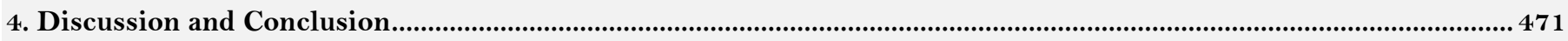

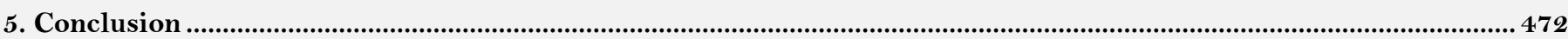

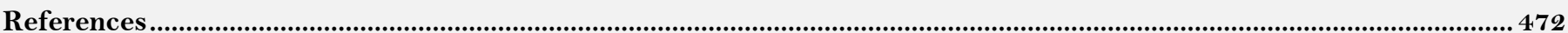




\section{Contribution of this paper to the literature}

This study is important in terms of determining the effect of whether university students studying sports going to Fitness Centers race in leisure time strategies as a competitor besides sports education. It does not matter whether students with sports education are racers for going to fitness centers in terms of leisure strategy.

\section{Introduction}

Leisure plays an important role in releasing stress and refreshing people's bad energies (Leitner \& Leitner, 2004; Torkildsen, 2005). People may be found in various forms of enjoyable engagement the demonstration of which varies depending on the context or an individualistic life circumstances at the today (Weinblatt \& Navon, 1995). Stress is a concept that can affect people in different areas of life and the search for ways to cope with it has turned it into a part of modern life (Shields, 2003). Although it is known in general that stress causes a psychological effect on humans, it also has a great number of physiological effects on the immune system and the nervous system (Aldwin, 2014). In coping with stress, the management of problems that cause stress are also effective in addition to getting away from stress (Iwasaki, MacKay, \& Mactavish, 2005). Exercise and physical activity help to achieve better physical and mental health, improve quality of life. Exercise is effective not only on health but also on many parameters including speed (Aksoy \& Ağaoğlu, 2017; Aksoy. \& Arslan, 2019). Leisure time is closely associated with coping with stress (Iwasaki, 2006). Dealing with different leisure time activities, participation in sport in leisure time, leisure activities that provide socialization and leisure activities in nature can decrease stress (Cevik, Ozcan, \& Munusturlar, 2018). Leisure comes across as different expressions in other societies, but in all of them, in general, leisure time, "getting rid of pressure", "moving from restrictions to freedom", "right to choose", "remaining time after work ", "remaining time after compulsory duties are done. "Is expressed. Spare time; After completing his professional, family and social duties, he is the time he spends to rest, have fun, develop some activities or voluntarily participate in community activities (Bedir, 2016). Sciences generally have moderate time management attitudes and have difficulty in using time. Most people complain that time is inadequate; but some people use time effectively and can do more. Understanding how this can happen is the most important issue (Köse \& Uzun, 2019). Denovan and Macaskill (2017) in a study, Leisure evaluation appeared to be helpful in coping with the stress the people report encountering in everyday life. Leisure is relevant to both emotion- and problem-focused coping and beliefs about leisure's role in coping influence the nature of the leisurebased coping strategy used. "Leisure coping beliefs refer to people's beliefs that their leisure helps them cope with stress". Leisure coping strategies are described as "actual situation-grounded behaviors or cognitions available through involvement in leisure". Leisure strategies can mood increase by modify appraisals of stressful situations. Leisure friendships for example, contribute about one's ability to use leisure good in stressful cases (Iwasaki \& Mannell, 2000; Kleiber, Brock, Lee, Dattilo, \& Caldwell, 1995). Leisure (free) time is a special area of human life. It includes alternative, creativity, content and pleasure. The concept of activity includes mostly physical and in addition multiple aspects of intellectual personality, image and spiritual events. The concept of leisure time is the times when the individual is free from all obligations or connections for both himself/herself and others and engages in an activity with his/her own will. Leisure time is defined as the time in which the individual does not work and spends with his/her own will, outside the obligations of life and official responsibilities (A $\breve{g}_{1} l o ̈ n u ̈, ~ 2007$; Kır, 2007). Leisure time can be explained with concepts such as being free of spiritual pressure, transition from restriction to freedom, and the time remaining after work or after fulfilling mandatory tasks. Individuals with leisure time have the opportunity to deal with recreation and recreational activities. The importance of leisure results from the fact that it meets individuals' needs to rest and have fun and strengthens their ties with life and makes them happy. The concept of leisure time constitutes a structural characteristic of the contemporary industrial society and a product of this society (Bedir, 2016; Karak, 2014).

Leisure time gives individuals of all ages the chance to be with friends without worrying about a financial income, removes the stress on working people and enables them to relax. It also allows individuals to continue living in a healthier condition by preparing them a suitable environment to have new knowledge and skills by providing escape from daily workload stress for a certain time with various activities. Making use of leisure time is the willing participation of individuals in any one or most of various activities to get pleasure and satisfaction within the time remaining from their vital needs. Making use of leisure time, which is expressed as people's getting away from the monotony of daily life by participating in various activities which are suitable for them and which make them happy and also as people's gaining a social personality by integrating with other individuals, is explained as social activities which are like a gift but which do not have purpose of income (Bedir, 2016; Gülbahçe, 1996). Leisure activities provide a psychological support with the belief in their use in coping with and managing stress (Iwasaki et al., 2005). Individuals who can make good use of time know what to do each moment. They use their time well and design their time according to the goals they set (Alay \& Koçak, 2003). Participation in leisure activities differ according to individuals' way of life, characteristics and their use of time. The type of activity, the way of participation and the time allocated to these are affected by a great number of factors. These factors can be listed as race, religion, social and personal characteristics, age and gender (Tolukan, 2010). Leisure friendship is expressed as the friendship individuals have through leisure recreational activities they do in their free time (Bedir, Bedir, Erhan, \& Şen, 2016). Although there is a study conducted by Bedir et al. (2016) on the beliefs of sport sciences faculty students for coping with stress through leisure time, it can be stated that new studies are needed since there are questions about the research's ability to measure the theoretical structure of coping with stress through leisure time. If we talk about the existence of leisure time in a place where there is time management, it is necessary to manage leisure time correctly and efficiently (Kırtepe \& Uğurlu, 2018). Leisure might act as a source of opportunities for renewal that Newman (2011) argues is a key feature of a sustainable career.

In this study, it was aimed to investigate Leisure Time Strategies of Sports Educated Students Going to Fitness Centers. 


\section{Material and Method}

\subsection{Study Group}

A total of 543 between the ages of 18 and 27 who were Sports Educated Students on fitness centers in the province of Samsun were included in the study. In addition to personal information, students filled in Scala "Strategies to Cope with Stress through Leisure Time Scale" before training. The scales which were fully completed were evaluated.

\subsection{Data Collection Tools}

Leisure Strategy Scale: The leisure strategies scale, developed by Iwasaki and Mannell (1999) was validated and validated in Turkish by Bedir (2016). Later, Çevik was re-validated and validated. In this study, the scale proposed by Cevik et al. (2018) was used. The scale is a 7-likert type scale. It is scored as Strongly disagree 1, disagree 2 ,somewhat disagree 3, neither disagree nor agree 4, somewhat agree 5 , agree 6 and strongly agree 7 . Turkish origin of the scale was determined as 8 items in total by Bedir (2016). The scale consisted of three subscales. These were leisure friendship (Items 2, 5, 7, 8, 15, and 18), leisure time temporary coping (Items 3, 4, 9, 11,14 , and 17) and leisure time mood improving (Items 1, 6, 10, 12, 13, and 16). Cevik et al. (2018) deleted item 15 from leisure friendship and item 12 and 13 from mood and calculated the scale with 15 items. 15 items were used in the present study. Internal consistency coefficient was found as 0.89 for leisure friendship, as 0.88 for leisure time temporary coping and as 0.87 for leisure time mood improving. Cronbach Alpha coefficient of the whole scale was 0.94 .

BMI $($ Body Mass Index $)=$ body weight $(\mathrm{kg}) /$ height $(\mathrm{m})^{2}=\mathrm{kg} / \mathrm{m}^{2}$.

\subsection{Data Analysis}

SPSS 23.00 program was used in the study. Kolmogorov-Smirnov test was conducted to find out whether the data were normally distributed. It was found that the data were normally distributed. Independent t-test was used for paired comparisons, while one-way ANOVA was used for multiple comparisons and LSD tests were conducted to find out differences.

\section{Results}

Table-1.Comparison of heights and weights of the participants according to age category.

\begin{tabular}{|c|c|c|c|c|c|}
\hline Parameter & Age category & $\mathbf{n}$ & Mean & SD & F/LSD \\
\hline \multirow[t]{4}{*}{$\overline{\text { Height }(\mathrm{cm})}$} & 20 and under years $(1)$ & 85 & 173.44 & 5.52 & \multirow[t]{4}{*}{2.01} \\
\hline & 21-23 years $(2)$ & 160 & 173.70 & 9.40 & \\
\hline & 24 and above years (3) & 298 & 173.41 & 7.35 & \\
\hline & Total & 543 & 174.35 & 7.93 & \\
\hline \multirow[t]{4}{*}{ Weight (kg) } & 20 and under years (1) & 85 & 73.87 & 8.79 & \multirow{4}{*}{$\begin{array}{c}10.42^{* * *} \\
3>1,2\end{array}$} \\
\hline & 21-23 years (2) & 160 & 76.12 & 9.81 & \\
\hline & 24 and above years (3) & 298 & 78.53 & 9.73 & \\
\hline & Total & 543 & 77.90 & 9.86 & \\
\hline \multirow[t]{4}{*}{ Body mass index $\left(\mathrm{kg} / \mathrm{m}^{2}\right)$} & 20 and under years $(1)$ & 85 & 24.62 & 2.36 & \multirow{4}{*}{$\begin{array}{c}5.23^{*} \\
3>1\end{array}$} \\
\hline & 21-23 years $(2)$ & 160 & 25.38 & 3.05 & \\
\hline & 24 and above years (3) & 298 & 26.24 & 2.91 & \\
\hline & Total & 543 & 25.41 & 2.93 & \\
\hline
\end{tabular}

According to age groups, the height of the students is similar. On the other hand, a statistically significant difference was found between students' body weights and body mass index values $(\mathrm{p}<0.05$ and $\mathrm{p}<0.001)$.

Table-2. Comparison of leisure strategy subscales and total scores according to age category.

\begin{tabular}{|c|c|c|c|c|c|}
\hline Scala and subscales & Age category & $\bar{n}$ & Mean & SD & F/LSD \\
\hline \multirow[t]{3}{*}{ Leisure friendship } & 20 and under years (1) & 85 & 25.08 & 8.21 & \multirow{3}{*}{$\begin{array}{l}4.10^{*} \\
1,2>3\end{array}$} \\
\hline & $21-23$ years $(2)$ & 160 & 24.60 & 9.36 & \\
\hline & 24 and above years (3) & 298 & 22.32 & 9.01 & \\
\hline \multirow[t]{3}{*}{ Temporary coping } & 20 and under years (1) & 85 & 29.42 & 9.09 & \multirow{3}{*}{$\begin{array}{l}3.99^{*} \\
3<1,2\end{array}$} \\
\hline & 21-23 years $(2)$ & 160 & 28.54 & 10.02 & \\
\hline & 24 and above years (3) & 298 & 26.10 & 10.03 & \\
\hline \multirow[t]{3}{*}{ Mood improvement } & 20 and under years (1) & 85 & 19.32 & 7.12 & \multirow{3}{*}{$\begin{array}{c}4.22^{*} \\
2>3\end{array}$} \\
\hline & $21-23$ years $(2)$ & 160 & 19.62 & 7.26 & \\
\hline & 24 and above years (3) & 298 & 17.52 & 7.21 & \\
\hline \multirow[t]{3}{*}{ Total score } & 20 and under years $(1)$ & 85 & 73.82 & 21.88 & \multirow{3}{*}{$\begin{array}{c}4.21^{*} \\
2>3\end{array}$} \\
\hline & 21-23 years $(2)$ & 160 & 72.78 & 21.62 & \\
\hline & 24 and above years (3) & 298 & 65.93 & 21.99 & \\
\hline
\end{tabular}

Note: ${ }^{*} \mathrm{p}<0.05$

There was a statistically significant difference between leisure strategy subscale and total scale scores by age groups $(\mathrm{p}<0.05)$. 
Table-3. Comparison of leisure strategy subscales and total scores according to the state of doing sport in the past.

\begin{tabular}{l|l|c|c|c|c}
\hline Scala and subscales & Category & n & Mean & SD & t-test \\
\hline \multirow{2}{*}{ Leisure friendship } & Students participating in competitions & 277 & 23.49 & 8.03 & \multirow{2}{*}{0.44} \\
& Students not participating in competitions & 266 & 23.14 & 9.01 & \\
\hline \multirow{2}{*}{ Temporary coping } & Students participating in competitions & 277 & 28.10 & 9.04 & 1.88 \\
& Students not participating in competitions & 266 & 26.32 & 9.20 & \\
\hline \multirow{2}{*}{ Mood improvement } & Students participating in competitions & 277 & 18.46 & 7.28 & \multirow{2}{*}{0.30} \\
\cline { 2 - 5 } & Students not participating in competitions & 266 & 18.26 & 7.38 & \\
\hline \multirow{2}{*}{ Total score } & Students participating in competitions & 277 & 70.05 & 25.48 & \multirow{2}{*}{0.97} \\
\cline { 2 - 5 } & Students not participating in competitions & 266 & 67.72 & 26.33 & \\
\hline
\end{tabular}

Note: ${ }^{*} \mathrm{p}<0.05$

Between students who participated in the competitions and the students who could not participate in the competitions there was no statistically significant difference between the leisure strategy subscales and total scale $(\mathrm{p}>0.05)$.

Table -4. Comparison of leisure strategy subscales and total scores according to body mass index category.

\begin{tabular}{|c|c|c|c|c|c|}
\hline Scala and subscales & BMI & $\bar{n}$ & Mean & SD & t-test \\
\hline \multirow[t]{2}{*}{ Leisure friendship } & $20-24,99 \mathrm{~kg} / \mathrm{m}^{2}$ & 269 & 22.86 & 9.12 & \multirow[t]{2}{*}{-1.06} \\
\hline & $25-27 \mathrm{~kg} / \mathrm{m}^{2}$ & 274 & 23.76 & 8.90 & \\
\hline \multirow[t]{2}{*}{ Temporary coping } & $20-24,99 \mathrm{~kg} / \mathrm{m}^{2}$ & 269 & 26.56 & 9.42 & \multirow[t]{2}{*}{-1.33} \\
\hline & $25-27 \mathrm{~kg} / \mathrm{m}^{2}$ & 274 & 27.83 & 9.85 & \\
\hline \multirow[t]{2}{*}{ Mood improvement } & $20-24,99 \mathrm{~kg} / \mathrm{m}^{2}$ & 269 & 17.99 & 8.43 & \multirow[t]{2}{*}{-1.09} \\
\hline & $25-27 \mathrm{~kg} / \mathrm{m}^{2}$ & 274 & 18.73 & 7.00 & \\
\hline \multirow[t]{2}{*}{ Total score } & $20-24,99 \mathrm{~kg} / \mathrm{m}^{2}$ & 269 & 67.42 & 26.40 & \multirow[t]{2}{*}{-1.20} \\
\hline & $25-27 \mathrm{~kg} / \mathrm{m}^{2}$ & 274 & 70.32 & 25.39 & \\
\hline
\end{tabular}

In this study, subscale and total scale scores were not significantly different according to Body Mass Index category $(\mathrm{p}>0.05)$.

Table-5. Comparison of leisure strategy subscales and total scores according to level of income.

\begin{tabular}{|c|c|c|c|c|c|}
\hline Scala and subscales & Parameters & $\bar{n}$ & Mean & SD & F/LSD \\
\hline \multirow[t]{4}{*}{ Leisure friendship } & Low (1) & 97 & 23.14 & 9.45 & \multirow{4}{*}{$\begin{array}{l}3.06^{*} \\
3>2,4\end{array}$} \\
\hline & Moderate (2) & 172 & 22.17 & 9.63 & \\
\hline & Good (3) & 153 & 25.24 & 8.51 & \\
\hline & Very good (4) & 121 & 22.61 & 8.47 & \\
\hline \multirow[t]{4}{*}{ Temporary coping } & Low (1) & 97 & 25.06 & 9.93 & \multirow{4}{*}{$\begin{array}{l}4.34^{*} \\
1<3,4\end{array}$} \\
\hline & Moderate (2) & 172 & 27.10 & 9.72 & \\
\hline & Good (3) & 153 & 29.34 & 9.53 & \\
\hline & Very good (4) & 121 & 27.68 & 9.38 & \\
\hline \multirow[t]{4}{*}{ Mood improvement } & Low (1) & 97 & 17.48 & 7.76 & \multirow{4}{*}{$\begin{array}{l}4.97^{*} \\
3>1,2\end{array}$} \\
\hline & Moderate (2) & 172 & 17.22 & 7.45 & \\
\hline & Good (3) & 153 & 20.29 & 6.64 & \\
\hline & Very good (4) & 121 & 18.43 & 7.10 & \\
\hline \multirow[t]{4}{*}{ Total score } & Low (1) & 97 & 64.46 & 27.89 & \multirow{4}{*}{$\begin{array}{l}3.93^{*} \\
3>1,4\end{array}$} \\
\hline & Moderate (2) & 172 & 68.67 & 27.49 & \\
\hline & Good (3) & 153 & 74.87 & 24.26 & \\
\hline & Very good (4) & 121 & 67.77 & 24.02 & \\
\hline
\end{tabular}

In this study, a statistically significant difference was found between the students' leisure strategies, subscale and total scale scores $(\mathrm{p}<0.05)$.

\section{Discussion and Conclusion}

It was found that average height of the students according to age category differed between 173.44 and 175.41 $\mathrm{cm}$. Average weight of the students was between 73.87 and $79.53 \mathrm{~kg}$. Body mass index values were found to be between 24.62 and $25.96 \mathrm{~kg} / \mathrm{m}^{2}$. According to age groups, the height of the students is similar. On the other hand, a statistically significant difference was found between students' body weights and body mass index values $(\mathrm{p}<0.05$ and $\mathrm{p}<0.001)$. Weight was found to increase with age category. Individuals with a body mass index value of 24$26.9 \mathrm{~kg} / \mathrm{m}^{2}$ and higher are considered as overweight (Hsu et al., 2018). The participants in this study can be considered as overweight at first start. In general, individuals with a body mass index of $25 \mathrm{~kg} / \mathrm{m} 2 \mathrm{are}$ considered as healthy, while those with a body mass index of higher than $25 \mathrm{~kg} / \mathrm{m}^{2}$ are considered as sick (Turgut, Akbulut, İmamoğlu, \& Çınar, 2018). However, this classification is for sedentary people individuals. Imamoğlu, Ağaoğlu, and Eker (2010) reported that body mass index of $25 \mathrm{~kg} / \mathrm{m}^{2}$ is normal for athletes. In this study, it can be said that in body weights for the age of 24 and over are within normal limits.

Bedir (2016) found average score as 5.93 for friendship subscale, as 5.53 for temporary coping subscale, as 6.14 for mood improvement and the total average as 5.87. In the present study, average score was found as 23.31 for friendship subscale, as 27.20 for temporary coping subscale, as 18.36 for mood improvement and the total average was found as 68.87. Average scores of both studies are different since the subjects were different.

In a study conducted by Coleman and Iso-Ahola (1993) it was stated that friendships through social activities decreased the feeling of loneliness and being isolated from the society and gave social support to individuals. Kır 
(2007) stated that young people did not show a high sensitivity in making use of their leisure time and added that they engaged in passive activities again and that spending their leisure time was limited. Uzun, İmamoğlu, Yamaner, Deryahanoğlu, and Yamaner (2017a) found a significant difference in individual psychology subscale in high school students in terms of age group. Uzun et al. (2017b) in a study, the state and frequency of doing sport can be found to increase enjoyment in physical activity. In their study, Demirtaş and İmamoğlu (2018) found that leisure perceptions of students differed in terms of age, study area and participation in recreational activities, while they were not found to differ in terms of grade and level of income. It was also reported that stress levels decreased in individuals who were doing sport (Ciçek, Imamoğlu, Yamaner, \& Türk, 2017; Deryahanoğlu, İmamoğlu, Yamaner, \& Uzun, 2016). Gencay, Geri, Tazegül, and Sezan (2019a) in a study, when the free time levels of the students were compared according to the age variable, no statistically significant difference was found. Aksoy (2020) in a study, found statistically significant difference in friendship, temporary coping, mood and total score of leisure strategy subscales according to age category. Kim (2009) indicated, that adolescents more from adult are involved in leisure activities. In this study, statistically significant difference was found in leisure time strategy subscale and total score according to age category $(\mathrm{p}<0.05)$. The participants in the third age category had lower scores. In leisure friendship, temporary coping and mood improvement subscales, average scores of 20 and under and 21-23 age groups were found to be higher when compared with the 24 and above age group. Besides the personal characteristics of the participants, the different age categories may cause differences.

It can be thought that some positive features acquired with competition sport (friendship development, getting away from anxiety and stress, etc.) show their effects in the long term, too. It is stated that when compared with individuals who do not do sports, individuals who do sports are more lively, extrovert, more hardworking, more patient, more ready to make social relationships and to adapt to a new situation and more stable emotionally (Yamak \& İmamoğlu, 2019). In this study, there was no statistically significant difference between the leisure strategy subscales and total scale the students who participated in the competitions and the students who could not participate in the competitions ( $p>0.05)$. However, the scores of students competing in sports competitions are higher than those who do not participate in competitions.

Individuals' being pleased with the external image of their bodies can cause them to think positively (Yamak, İmamoğlu, İslamoğlu, \& Çebi, 2018). In the present study, there were no statistically significant differences between scale scores of the participants within normal health limits and the participants who were according to body mass index ( $>0.05)$. It can be said that students' body mass index is above $25 \mathrm{~kg} / \mathrm{m} 2$ and that it is below it has no effect on leisure strategies. Among the reasons for students who are already studying sports was going to fitness centres, there can condition progress and muscular development. They may also know that it is normal for them to have more body weight for them than normal people, since they receive sports training.

Ozdilek, Demirel, and Harmandar (2007) in a study, found frequency of participation in recreational activities and who do not have sufficient income participate less in recreational activities than people with higher income. In addition, in her study, Oguz (2000) revealed that as the amount of money received by students increases, the amount of money spent for leisure activities increases. Aksoy (2020) in a study, found a significant difference between to the ones with good income and those with low income for leisure time strategy. Bedir (2016) did not find significant difference between monthly income and leisure time strategy subscale scores and total scores of students in the faculty of Sport Sciences. Gencay, Geri, and Tazegül (2019b) in a study, according to the gender, age, level of income and regular sports, it was found that leisure time attitudes did not differ. In the present study, significant difference was found in all subscales and total scale score according to the level of income $(\mathrm{p}<0.05)$. It is thought that the students with a good level of income have better strategies to cope with stress through leisure time. It is compulsory to consider several factors, including the leisure time on the relationship between leisure participation (Shin \& You, 2013).

\section{Conclusion}

In addition to sports education, leisure strategies of university students doing sports in Fitness centers differ according to age category and income status. Whether or not attending competitions showed no difference between students who study sports going to fitness Center. It has that whether or not participating in competitions in sports training students, who going fitness Centre does not have a different effect in terms of leisure strategies. The fact that the participation of the competitions in terms of leisure strategies between the two students group does not differ can be attributed to the sports education they receive. In terms of leisure strategies, this study is recommended to be done according to the status of being an amateur and professional athlete in sports-inclined students.

\section{References}

Ağılönü, A. (2007). Recreation services and model determination in local governments: Fethiye example. Unpublished Doctoral Dissertation, Marmara University, Istanbul.

Aksoy, Y. (2020). Investigation of leisure time strategies of people through fitness centers. Atatürk University Journal of Physical Education and Sports Sciences, 22(1), 55-63.

Aksoy, Y., \& Ağaoğlu, S. A. (2017). The comparison of sprint reaction time and anaerobic power of young football players, volleyball players and wrestlers. Kinesiologia Slovenica, 23(2), 5-14.

Aksoy, Y., \& Arslan, O. (2019). Effects of recreational activity on leisure barriers between students. Asian Journal of Education and Training, 5(4), 569-574.Available at: https://doi.org/10.20448/journal.522.2019.54.569.574.

Alay, S., \& Koçak, S. (2003). The relationship between university students' time management and academic success. Journal of Education Management in Theory and Practice, 9(3), 326-335.

Aldwin, C. M. (2014). Stress, coping, and development: An integrative perspective. New York: Guilford Publications.

Bedir, F. (2016). Investigation of the role of leisure (recreational) activities to overcome stress. Atatürk University, Institute of Social Sciences, Department of Sports Management Master Thesis.

Bedir, F., Bedir, D., Erhan, S., \& Şen, İ. (2016). Turkish validity and reliability study of the coping belief scale for coping with leisure time stress. Atatürk University Journal of Physical Education and Sports Sciences, 18(4), 9-16.

Cevik, H., Ozcan, Ö., \& Munusturlar, S. (2018). Leisure through faith coping with stress scale and leisure strategy through coping with stress scale factor structure of the sample testing towards Turkey: Validity and reliability study. SPORMETR, 17a(2), 36-50. 
Ciçek, G., Imamoğlu, O., Yamaner, F., \& Türk, N. (2017). Psychological effects of Cardio Bosu exercise on sedentary women. International Journal of Sports, Exercise and Training Science, 3(3), 69-75.

Coleman, D., \& Iso-Ahola, S. E. (1993). Leisure and health: The role of social support and self-determination. Journal of Leisure Research, 25(2), 111-128.Available at: https://doi.org/10.1080/00222216.1993.11969913.

Demirtaş, Ö., \& İmamoğlu, G. (2018). Research of leisure barriers in university students receiving sports and art education, sports and wellness researches for everyone (Editors: M. Ali Öztürk, Süleyman Gönülateş) (pp. 369-381). Ankara: Academician Bookstore.

Denovan, A., \& Macaskill, A. (2017). Building resilience to stress through leisure activities: A qualitative analysis. Annals of Leisure Research, 20(4), 446-466.Available at: https://doi.org/10.1080/11745398.2016.1211943.

Deryahanoğlu, G., İmamoğlu, O., Yamaner, F., \& Uzun, M. (2016). Anthropometric characteristics of sedentary women and comparison of their psychological states. Journal of Human Sciences, 13(3), 5257-5268.Available at: https://doi.org/10.14687/jhs.v13i3.4106.

Gencay, E., Geri, S., \& Tazegül, Ü. (2019b). Investigation of leisure attitude levels of Mardin Artuklu University coaching education department students. Paper presented at the 2nd Eurasian Sports Sciences Congress, Book of Full Text, Muş.

Gencay, E., Geri, S., Tazegül, Ü., \& Sezan, T. (2019a). Investigation of leisure management levels of Mardin Artuklu University coaching education department students. Paper presented at the 2nd Eurasian Sports Sciences Congress, Book of Full Text, Muş.

Gülbahçe, Ö. (1996). Leisure time habits, (Unpublished Master Thesis). Erzurum: Atatürk University, Institute of Social Sciences.

Hsu, C.-C., Wahlqvist, M. L., Wu, I.-C., Chang, Y.-H., Chang, I.-S., Tsai, Y.-F., \& Hsiung, C. A. (2018). Cardiometabolic disorder reduces survival prospects more than suboptimal body mass index irrespective of age or gender: A longitudinal study of 377,929 adults in Taiwan. BMC Public Health, 18(1), 142.Available at: https://doi.org/10.1 186/s 12889-018-5038-0.

Imamoğlu, O., Ağaoğlu, Y., \& Eker, H. (2010). The investigation of nutritional habits of department of physical education and sports students in different cities. Journal of Physical Education and Sport Science, 12(4), 1-12.

Iwasaki, Y., MacKay, K., \& Mactavish, J. (2005). Gender-based analyses of coping with stress among professional managers: Leisure coping and non-leisure coping. Journal of Leisure Research, 37(1), 1-28.Available at: https://doi.org/10.1080/00222216.2005.11950038.

Iwasaki, Y., \& Mannell, R. C. (1999). The effects of leisure beliefs and coping strategies on stress-health relationships: A field study. Leisure/Loisir, 24(1-2), 3-57.Available at: https://doi.org/10.1080/14927713.1999.9651258.

Iwasaki, Y., \& Mannell, R. C. (2000). Hierarchical dimensions of leisure stress coping. Leisure Sciences, 22(3), 163-181.Available at: https://doi.org/10.1080/01490409950121843.

Iwasaki., Y. (2006). Counteracting stress through leisure coping: A prospective health study. Psychology, Health $\mathcal{E}^{2}$ Medicine, 11(2), 209220.Available at: https://doi.org/10.1080/13548500500155941.

Karak, K. S. (2014). Recreation: Leisure (7th ed.). Ankara. Turkey.

Kim, S. (2009). Relation between adolescents' level of involvement in recreational activities and emotional expression and confidence for recreation. Journal of Leisure and Recreation Studies, 33(2), 135-144.

Kır, İ. (2007). Leisure activities of higher education youth: The case of KSU. Firat University Journal of Social Sciences, 17(2), $307-328$.

Kırtepe, A., \& Uğurlu, M. F. (2018). Determination of the leisure time management of individuals who go to gym for recreation purposes, according to distinctive variables. Turkish Studies, 13(3), 783-792.

Kleiber, D. A., Brock, S. C., Lee, Y., Dattilo, J., \& Caldwell, L. (1995). The relevance of leisure in an illness experience: Realities of spinal cord injury. Journal of Leisure Research, 27(3), 283-299.Available at: https://doi.org/10.1080/002222 16.1995.1 1949749.

Köse, B., \& Uzun, M. (2019). Time management behavior of students studying in sports sciences. Journal of Sports Sciences Turkey, 3(2), 82-87.

Leitner, M. J., \& Leitner, S. F. (2004). Leisure enhancement (3rd ed.). New York: The Haworth Press.

Newman, K. L. (2011). Sustainable careers. Organizational Dynamics, 40(2), 136-143.

Oguz, D. (2000). User surveys of Ankara's urban parks. Landscape and Urban Planning, 52(2-3), 165-171.Available at: https://doi.org/10.1016/s0169-2046(00)00130-4.

Ozdilek, C., Demirel, M., \& Harmandar, D. (2007). The comparasion of Dumlupinar and Sakarya Universities' Physical education and sport school students' participation reasons and participation level in leisure time activities. Journal of Human Sciences, 4(2), 1-13.

Shields, M. (2003). Stress, health and the benefit of social support. Health Reports, Catalogue No. 82-003-XPE, 15(1). Ottawa: Statistics Canada.

Shin, K., \& You, S. (2013). Leisure type, leisure satisfaction and adolescents' psychological wellbeing. Journal of Pacific Rim Psychology, 7(2), 53-62.Available at: https://doi.org/10.1017/prp.2013.6.

Tolukan, E. (2010). Determination of factors that may prevent participation of university students studying in special talent departments in recreational activities. Master Thesis, Niğde University Institute of Social Sciences, Niğde.

Torkildsen, G. (2005). Leisure and recreation management. London: Routledge.

Turgut, M., Akbulut, T., İmamoğlu, O., \& Çınar, V. (2018). The effect of 3 month Cardio Bosu exercises on some motoric, physical and physiological parameters in sedentary women. Sport \&o Societ, 18(2), 48-52.

Uzun, M., İmamoğlu, O., Yamaner, F., Deryahanoğlu, G., \& Yamaner, G. (2017a). Examination of the factors which prevent to participate the recreative activities: Example of girls high school Rekreatif etkinliklere katılımı engelleyen faktörlerin incelenmesi: Kız lisesi örneği. Journal of Human Sciences, 14(1), 950-962.Available at: https://doi.org/10.14687/jhs.v 14i 1.4174.

Uzun, M., Yurdadön, Ü., İmamoğlu, O., Çon, M., Çavuşoğlu, G., \& Taşmektepligill, M. Y. (2017b). Determination of secondary schools participation in sportive activities and states of enjoying physical activities. Inonu University, Journal of Physical Education and Sport Sciences, 4(1), 38-52.

Weinblatt, N., \& Navon, L. (1995). Flight from leisure: A neglected phenomenon in leisure studies. Leisure Sciences, 17(4), 309-325.Available at: https://doi.org/10.1080/01490409509513265.

Yamak, B., \& İmamoğlu, O. (2019). The beck hopelessness level according to behavior change stages in University Ondokuz Mayis students. Turkish Studies Educational Sciences, 14(3), 937-947.

Yamak, B., İmamoğlu, O., İslamoğlu, İ., \& Çebi, M. (2018). The effects of exercise on body posture. Turkish Studies Social Sciences, 13(18), $1377-1388$. 